\title{
Social Security Pension Reform in China
}

\section{Citation}

Feldstein, Martin. 1999. Social security pension reform in China. China Economic Review 10, No. 2: 99-107

\section{Published Version}

http://dx.doi.org/10.1016/S1043-951X(99)00007-3

\section{Permanent link}

http://nrs.harvard.edu/urn-3:HUL.InstRepos:2794835

\section{Terms of Use}

This article was downloaded from Harvard University's DASH repository, and is made available under the terms and conditions applicable to Other Posted Material, as set forth at http:// nrs.harvard.edu/urn-3:HUL.InstRepos:dash.current.terms-of-use\#LAA

\section{Share Your Story}

The Harvard community has made this article openly available.

Please share how this access benefits you. Submit a story.

Accessibility 


\title{
SOCIAL SECURITY PENSION REFORM IN CHINA
}

\author{
Martin Feldstein
}

Working Paper 6794

http://www.nber.org/papers/w6794

\section{NATIONAL BUREAU OF ECONOMIC RESEARCH \\ 1050 Massachusetts Avenue \\ Cambridge, MA 02138 \\ November 1998}

The views expressed here are those of the author and do not reflect those of the National Bureau of Economic Research.

(C) 1998 by Martin Feldstein. All rights reserved. Short sections of text, not to exceed two paragraphs, may be quoted without explicit permission provided that full credit, including $\mathbb{C}$ notice, is given to the source. 
Social Security Pension Reform in China

Martin Feldstein

NBER Working Paper No. 6794

November 1998

JEL No. H55

\section{ABSTRACT}

China has legislated a mixed social security pension system with a defined benefit pay-asyou-go portion and an investment-based defined contribution portion. This paper analyses the economics of these two types of systems in the Chinese context and calculates the advantage to China of using an investment-based portion. Several options for reform of the recently legislated system are considered.

Martin Feldstein

National Bureau of Economic Research 1050 Massachusetts Avenue

Cambridge, MA 02138

msfeldst@nber.org 
msfeldst@nber.org

\title{
Social Security Pension Reform in China
}

\author{
Martin Feldstein*
}

The reform of social security pensions is a critical issue for China-a key to enterprise reform, sound public finance, and the well-being of current and future retirees. China has already begun to develop an investment-based system of individual accounts for urban workers, especially those in state owned enterprises. Looking to the future, China faces important issues both about improving the design and implementation of this system and about the transition from the existing unfunded system to the new arrangements.

\section{1. $\quad$ Principles of Social Security Pension Design}

A useful starting place for any academic discussion of pensions is the famous article by Paul Samuelson (1958) in which he showed that in equilibrium a completely unfunded pay-as-you-go (PAYGO) pension system has a positive real rate of return equal to the rate of growth of aggregate real wages, i.e., to the sum of the growth rate of the population and the growth rate of productivity. Samuelson's theoretical analysis assumed an economy with no capital stock and showed that in such

*Professor of Economics, Harvard University, and President of the National Bureau of Economic Research. This paper is based on a talk given at the June 1998 Beijing conference of the Chinese Economics Society. Although my original plan for this lecture was to discuss the social security reforms occurring around the world (based on the information in Feldstein, 1998), I decided instead to talk about the current policies in China and some of China's options for the future. My decision is a risky one since I am certainly not a specialist on the Chinese economy. I recognize that some of my assumptions about the economy and about the current pension arrangements may be wrong, especially since those arrangements are changing rapidly and practice does not always correspond to the official rules. Several useful articles about the Chinese pension system are identified in the references to this paper. 
a context a pay-as-you-go pension is a desirable policy.

Actual economies do have capital stocks and the marginal product of capital is greater than the growth rate of aggregate wages. This implies that a nation can buy retirement income with a funded pension system at a lower long-run cost than with a pay-as-you-go system, i.e., the savings deposits in a funded system are less than the tax required in a PAYGO system to provide the same level of benefits.

There is nevertheless a political temptation in any country to adopt a PAYGO system because doing so permits giving a windfall benefit to current retirees and to those who will soon be retired with the cost of that windfall deferred to future taxpayers. Many countries have succumbed to that temptation since Bismark introduced the first formal pension system in Germany in the nineteenth century. And countries with PAYGO systems have created new windfalls from time to time by increasing benefits and expanding coverage, thus maintaining the popularity and political support for the PAYGO system.

But now countries around the world with PAYGO systems are recognizing that there is no more scope for increased windfalls. There is a realization that the increasing longevity of populations everywhere means that tax rates will have to rise in the future just to maintain the current relation between retiree benefits and preretirement wages. As a result, we are seeing a shift from PAYGO to funded systems in a number of countries and the active consideration of such reforms in others.

China is already beginning the transition for workers in state owned enterprises from its unique PAYGO system to a partially funded system based on individual accounts. To the extent that China succeeds in this shift from a PAYGO to a funded system, it will keep future taxes lower than they would otherwise be, will help to develop a more efficient capital market, and will facilitate both 
the management and privatization of the currently state-owned enterprises.

The choice between a PAYGO system and a funded system is only one of the two important aspects of designing a pension system. The second key characteristic is the choice between a defined benefit and a defined contribution system. In a defined benefit program, retirees receive benefits based on a formula that typically involves the number of years of work and the past history of wages. In contrast, in a defined contribution program, employees (and/or their employers) make contributions to individual accounts during working years. The balances in these accounts earn a rate of return based on the assets in which those funds are invested. Retirees then receive an annuity based on the amount accumulated in their accounts.

It is of course possible to have a mixed system that combines defined benefits and defined contributions. In 1995 China adopted such a combined two-tier system. Participants will receive a defined benefit financed by pay-as-you-go taxes and also participate in a defined contribution program to which employers and employees both contribute. I return below to discuss both aspects of this system.

It is also possible to have a conditional defined benefit system. In such a system, individuals have defined contribution accounts but are also guaranteed a minimum amount (a defined benefit). Any shortfall between the annuity provided by the defined contribution account and the guaranteed defined benefit amount is made up by the government.

Around the world, social security reforms now generally involve moving from pay-as-you-go defined benefit systems to funded (investment based) defined contribution systems, often with some form of conditional defined benefit guarantee. Other combinations are possible. A government defined benefit plan can be financed by accumulating a centralized government fund that is invested 
in new capital. In yet a different approach, some governments are introducing defined contribution plans with individual accounts that are nevertheless operated as a pay-as-you-go system. Such unfunded defined contribution systems provide a notional rate of return, i.e., an accounting rate of return without any real capital accumulation. Such notional unfunded defined contribution systems provide a lower rate of return than a funded system; to be sustainable, the promised return in such an unfunded system must not exceed the rate of growth of total wages.

\section{2. $\quad$ Potential Chinese Gain from an Investment Based System}

Before discussing the specific features of the current Chinese system, I will use some estimated Chinese figures to discuss the magnitude of the advantage of an investment based system and the extent to which an investment based system can reduce the long-term cost of providing a given level of retirement benefits.

Consider the following example of a PAYGO system. Assume that there are 3 workers per retiree. The benefits given to retirees are 60 percent of the average wage. That implies that the tax rate must be 20 percent of wages. What does it cost to provide the same 60 percent benefit with a funded system? That depends on the future growth of aggregate wages and the future productivity of capital investments.

The World Bank estimates that over the next several decades as a whole real aggregate wages in China will grow at about 7 percent or less per year (World Bank, 1997). I do not know what the marginal product of capital will be in China in the future. But Gregory Chow (1993) estimates that the marginal product of industrial capital in China has been 17 percent, with a higher return on construction and a lower return on residential and retail capital. I will be very conservative and assume that in the future the real marginal return on capital will be only 12 percent. A higher rate 
of return would make a funded system even more attractive.

What do these two numbers imply? In a pay-as-you-go system the tax "contributions" earn an implicit rate of return equal to the rate of growth of aggregate wages which, looking ahead in China, can be taken to be approximately 7 percent. Consider an individual who contributes to the PAYGO system from age 25 to age 64 and then receives benefits from age 65 to 85 . To simplify the calculation so that the nature of the result is transparent, assume that the contributions are all made at the midpoint of the working years (i.e., at age 45) and that the benefits are paid at the midpoint of the retirement years, i.e., at age 75 . The funds are therefore earning a 7 percent implicit rate of return for the 30 years from age 45 to age 75 . At 7 percent, one dollar saved at age 45 grows to $\$ 7.60$ at age 75 . In these calculations, all amounts are of course measured in the same price levels.

Compare this now with the effect of saving in a funded system with a 12 percent rate of return. One dollar saved at age 45 grows to $\$ 30$ at age 75 , about four times as much as in a PAYGO system in an economy with a 7 percent growth rate of aggregate real wages.

The implication of this is that the funded system can provide the same level of benefits with a saving rate equal to only one fourth of the rate of tax required in the PAYGO system. If the PAYGO system requires a tax equal to 20 percent of wages to provide a given level of benefits (e.g., benefits equal to 60 percent of concurrent wages), a funded system with a 12 percent rate of return on capital (in comparison to the 7 percent rate of growth of aggregate real wages) can provide the same benefits with savings equal to 5 percent of wages.

This represents an enormous long-run "tax" saving, requiring individuals to set aside 5 percent of their wages during each working year instead of 20 percent. This not only increases the spendable income of future employees but also reduces the distortionary effect and deadweight loss of high 
marginal tax rates.

This calculation is about the long-run. What about the transition from a pay-as-you-go system to a funded system? Critics of such a transition argue that it would require current employees to "pay double". That seems to imply that if there is a tax equal to 20 percent of wages now, during the transition to a funded system the combination of the tax required to finance existing benefits and the saving required to fund future benefits would be double that or 40 percent.

Such a statement is wrong in two ways. Most important, the cost of funding future benefits is far less than the cost of the PAYGO system, a 5 percent saving rate in comparison to the 20 percent tax rate in the previous example. So the maximum additional cost to current employees would be the 5 percent required to fund their own future retirement annuities. Second, the PAYGO tax that starts at 20 percent would gradually decline over time during a transition as new retirees draw on their funded individual accounts as a source of retirement income.

As a result, a transition is feasible with only a very modest increase in the combined tax-plussavings rate in the early years and this combined burden would gradually decline and eventually become less than the initial PAYGO tax rate (see Feldstein and Samwick, 1997, 1998).

\section{The Current Social Security Pension System in China}

Since 1995, most municipalities and provinces in China have adopted a two-part plan for workers in state owned enterprises. The first part of this plan states that retirees in the future will receive a defined benefit financed by a PAYGO system. More specifically, employees who have worked for 40 years are scheduled to receive benefits equal to 25 percent of the regional average wage, with a proportional reduction for those with shorter work histories in these state-owned enterprises. This benefit would be financed by a payroll tax that the authorities estimate will equal 
9 percent of wages. This implicitly assumes that there will be about three workers per retiree (literally 25 workers per 9 retirees).

The second part of the plan is a defined contribution system. Current employees and their enterprises contribute 10 percent of wages to individual accounts managed by municipal or provincial authorities. Government calculations imply that the resulting annuity benefits would replace about 35 percent of individual's final year's earnings.

The official guidelines for this plan specify that 80 percent of the accumulated funds are to be invested in government bonds and 20 percent in bank deposits. In practice, some funds are said to be diverted into investments in local projects in pursuit of higher yields. The real returns on government bonds and bank deposits have been very low and in some recent years have actually been negative.

As one considers this new plan, an important question is whether the funding of the defined contribution part really represents new incremental capital? Or is it really just a notional PAYGO plan with no impact on national capital accumulation (as the World Bank implies in its 1997 report)?

This cannot be resolved by looking at the fact that the personal retirement accounts are invested primarily in government bonds. It depends on whether the bonds purchased for the personal retirement accounts would otherwise have been sold to the public (including the banks), thus crowding out other borrowing by enterprises.

If the existence of these defined contribution accounts causes the government of China to run correspondingly larger budget deficits, then there is no increase in capital accumulation and the defined contribution accounts are purely notional investments like any other PAYGO system. This would be true because the government would then have to raise future taxes to pay interest (and 
possibly principal) on these additional government bonds.

But while that is a logical possibility, I see no reason to believe that the existence of these defined contribution accounts does cause (or will cause) the government of China to run larger budget deficits. If my inference is correct, the additional saving that is accumulated in these defined contribution accounts represent increases in the nation's capital stock. The individuals and financial institutions that would otherwise buy the government bonds purchased by the defined contribution accounts will now buy other private market securities.

What is the rate of return earned on the incremental saving? If I am correct that the defined contribution deposits represent increased national saving and are not offset by increases in the government's budget deficit, the real rate of return on these incremental savings is the double digit marginal product of capital (assuming also that the imperfections and misallocations in the capital markets do not cause too much reduction in the effective rates of return.) This is true at the margin for changes in the defined contribution saving even if the government has a budget deficit and uses some of the defined contribution funds to finance that deficit as long as the amount of deficit financing does not increase with increases in the amount of defined contribution funds.

The fact that the defined contribution accounts are credited with much lower real rates of interest than the 12 percent marginal product of capital reflects an implicit tax that the government levies by requiring these defined contribution balances to be invested in government bonds and bank deposits with low rates of interest, a tax which reached 100 percent in recent years when the real rate of interest was driven to zero.

As restrictions on investments are relaxed in the future, these defined contribution accounts will invest in non-government securities - i.e., in enterprise stocks and bonds - and earn higher 
returns.

According to official Chinese projections, the 10 percent defined contribution rate is expected to provide an annuity equal to 35 percent of the pre-retirement wage. With a seven percent growth of real wages, this relation between the defined contribution rate and the replacement rate implies a real rate of return of only about 4 percent. If the defined contribution accounts could earn a real return equal to the 12 percent marginal product of capital, the proposed crediting of a four percent real return is equivalent to an effective tax rate of about 65 percent on the defined contribution return. ${ }^{1}$

If broadening the allowable set of investment options eventually allows a higher rate of return, the same benefits can be financed with a lower contribution rate or the same 10 percent contribution rate can be used to obtain a higher level of benefits. For example, doubling the return from 4 percent to 8 percent would permit cutting the contribution rate from 10 percent to 5 percent while simultaneously raising the replacement rate from 35 percent to 60 percent.

The promise of future social security pension benefits can induce households to decrease their own direct saving. The exact extent of this displacement is unclear but a credible promise of benefits equal to more than 60 percent of preretirement wages substantially reduces an individual's perceived need for other retirement income. Such a reduction in other saving can of course only occur if the individuals would otherwise have a high saving rate. As I understand the official Chinese statistics, households currently save a very large fraction of their incomes, an average of more than 25 percent.

${ }^{1}$ Since the contribution rate in the individual account is fixed by law, the high tax rate on the return to that saving does not distort saving decisions. The tax is in effect a payroll tax rather than a capital income tax. It distorts work incentives rather than saving incentives. Whether this is a good way to collect such revenue in the Chinese context deserves a careful examination. 
I do not know how that average is distributed among different kinds of employees and between urban and rural sections of the workforce. But with overall saving so high, it is natural to consider the possibility that the provision of social security causes a substantial reduction in other household saving. In the extreme, a funded defined contribution plan could displace an equal amount of existing saving, leaving no net change in national saving. Similarly, a promise of benefits in a PAYGO system could reduce private saving with no offsetting rise in government or pension saving, thus causing a net decease in national saving.

The key point to note is that, regardless of the induced reduction in other saving, a funded plan still causes a higher national saving rate than an unfunded PAYGO plan. The PAYGO plan with the same benefits would displace an equal amount of household saving - but unlike a funded plan would have no pension saving with which to replace it.

\section{4. $\quad$ Alternative Options for the Chinese Defined Benefit Plan}

I return now to the first tier of China's new social security pension system: the flat rate benefit equal to 25 percent of the average regional wage for those who have worked the full 40 years.

The rationale for providing such a benefit in addition to the defined contribution annuity is clear: some individuals with low lifetime earnings would have unacceptably low retirement incomes if they had to depend only on the defined contribution plan. The uniform defined benefit part of the pension would raise the total pension income and guarantee that it is at least equal to 25 percent of the average wage in the region.

It is however possible to achieve this goal in a much more cost effective way by modifying this part of the pensions system in either of two ways (or in both ways).

The first possible modification would be to substitute a funded system for the currently 
planned PAYGO financing. According to official calculations, the PAYGO financing is expected to require a nine percent payroll tax on top of all of the others taxes and mandatory contributions. Substituting a funded plan - based on investments in existing government bonds or non-government enterprise securities - could cut the cost by a factor of three or four, from a 9 percent tax to just three percent or less. This would achieve a major reduction in the distortions caused by the Chinese tax system as a whole.

The second possible modification would be to focus or target the defined benefit pension on those with unsatisfactorily low Tier 2 defined contribution pensions instead of giving the full defined benefit payment to all retirees. Stated differently, this part of the overall pension could be a conditional defined benefit -- filling the gap between the defined contribution annuity and the level of retirement income that is regarded as acceptable. If such a reform has the effect of focusing these benefits on the lower income half of annuity recipients, the financing cost would be cut by more than 50 percent.

A targeted or conditional defined benefit pension would not be a general means tested program but would focus on the shortfall associated with the defined contribution plan. It would therefore not have adverse effects on work or other saving. The combined effect of both of these options would be to reduce the required tax from the projected 9 percent to less than 2 percent of earnings.

\section{The Transition Path}

China must deal with the existing retirees and those who will soon retire as well as with the long-term problem of future retirees.

The magnitude of the existing unfunded liabilities to current retirees and workers are 
particularly difficult to assess in the Chinese context. In the past, retirement benefits were paid by the worker's enterprise without any explicit pension fund or accounting reserves. Often enterprises simply continued to pay the preretirement wage to workers when they reached retirement age and stopped working. These payments to retirees automatically reduced any surplus that the enterprise would otherwise have earned. And if it led the firm to a net loss, that loss would be absorbed by the central government or as nonperforming bank loans. In effect, the past system of providing retirement income to employees of state enterprises was effectively a PAYGO system of defined benefits linked to the final wage and administered by the retiree's lifetime workplace.

Now China is adjusting to the change in enterprise ownership and in lifetime work patterns. Even state owned enterprises must face a more rigorous market test and are not supposed to incur losses. As part of this shift to a more market based system, the enterprises' current pension obligations have been transferred to municipal or provincial governments. Enterprises as a whole are still taxed to meet these inherited obligations but the tax is no longer based on the specific retiree obligations of the particular enterprise.

Although such a shift of obligations from the enterprises to the government may help the transition to a more market based system of corporate management and facilitate greater employee mobility, it is not a necessary concomitant of the move to market based principles for corporate management and employment. In the United States, when companies have unfunded obligations for private pensions, this is reflected in lower share prices (reflecting lower future net earnings). If the unfunded pension obligations are so large that they imply losses in all future years and a negative present value of the company's future earnings, the company is technically bankrupt. Shareholders have no residual value. Pensioners are then paid by a government insurance fund (the Pension Benefit 
Guarantee Corporation). This is of course the extreme case. Usually, unfunded pension obligations are not that large, leaving a positive stream of future earnings and therefore positive but diminished share values. In Germany and certain other European countries, there is no external funding of private pensions and the unfunded company pension obligations are reflected in earnings and share values. China could in principle have followed this approach, leaving the unfunded obligations with the Chinese enterprises. In practice however this may be harder in present-day China than in the United States or Germany because it is harder to enforce a profitability test on state owned enterprises that lack the discipline of share prices and experienced arms-length banks.

Even with the shift of pension obligations from enterprises to government agencies, there is much talk in China about ways to provide collateral for these obligations. Although explicit government bonds might be a useful way to guarantee a future income stream to the pension beneficiaries, the discussion is generally about providing some form of real capital as collateral. Suggestions include transferring to the pension fund an explicit claim on land rents or on the income generated by some other state owned enterprises. In my judgement, the concern about collateralizing the existing pension obligations with a transfer of existing assets from the state is largely irrelevant. If the local or provincial government now owns an asset, there is no real difference between giving the associated income stream - e.g., the rental income on land or existing housing -- and giving a new government bond with the same stream of payments. Collateralizing the obligation of the government is largely irrelevant. This is particularly true if the obligations are regarded as ultimately the obligations of the central government that have been transferred to municipal and provincial governments for administrative reasons.

It would of course be different if designating some real asset as collateral causes it to be used 
differently, i.e., if the collateral owner is not merely the passive recipient of an income stream but is able to manage the use of the asset to achieve greater output and profitability. To the extent that the pension reforms can be used to put assets into the hands of better managers with clearer motives and incentives, the result will be to improve the use of China's resources.

But even if shifting assets to entities responsible for pension benefits causes them to be better managed, such a shift is economically efficient only if it leads to the best use of those resources among all the politically feasible options. If it is not, it would increase national income more if China privatized the state assets or land or housing in the most efficient available way and then gave bonds to current employers, employees or pension institutions to acknowledge the government's future obligations. If the World Bank is correct in its assessment of the value of these obligations, the bonds could be amortized over a 40 year period by a tax of about 1.5 percent of GDP.

\section{6. $\quad$ Concluding Comment}

China is noteworthy for its decision to develop a mixed system of defined benefit and defined contribution social security pensions. In doing so, it can provide protection for future retirees while strengthening national saving and expanding the market for enterprise securities. A greater emphasis on funded benefits and a shift from an unconditional defined benefit system to a conditional defined benefit guarantee would reduce the distortionary taxes and focus assistance on those in greatest need. The current system focuses on a limited fraction of the population, primarily urban workers in state owned enterprises. But the experience gained in doing this and thinking about this population can provide the basis for a stronger national system that can eventually provide retirement security for the entire Chinese population. 
Cambridge, Massachusetts

June 1998

\section{References}

Chow, Gregory C. "Capital Formation and Economic Growth in China," Quarterly Journal of Economics, 1993, 108(3): pp 809-42.

Feldstein, Martin. Privatizing Social Security, Chicago: University of Chicago Press, 1998.

Feldstein, Martin and A. Samwick. "The Transition Path in Privatizing Social Security," in Privatizing Social Security, Chicago: University of Chicago Press, pp 215-65, 1998.

Feldstein, Martin and A. Samwick. "The Economics of Prefunding Social Security and Medicare Benefits," in NBER Macroeconomics Annual 1997, (eds.) B. Bernanke and J. Rotemberg, Cambridge: The MIT Press, pp 115-147, 1997.

Freidman, Barry and Leonard Hausman. "Sustainable Social Protection in China: Concluding 
the Reforms.” Mimeo, 1998.

Hu, Aidi. "Reforming China's Social Security System: Facts and Perspectives," International Social Security Review, Vol. 50, No. 3, 1997, pp 45-60.

Hussain, Athar. "Social Security in Present-Day China and Its Reform," American Economic Review, 84:2, 1994, pp 276-80.

Samuelson, Paul A. "An Exact Consumption Loan Model of Interest With or Without the Social Contrivance of Money," Journal of Political Economy, 1958, Vol. 66, pp 467-82.

Song, Shunfeng and G. Chu. "Social Security Reform in China: The Case of Old Age

Insurance," in Contemporary Economic Policy, April 1997, Vol. XV, pp 85-93.

West, Loraine. "Pension Reform in China: Preparing for the Future,” Journal of Development

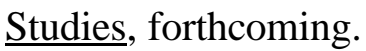

The World Bank, Old Age Security: Pension Reform in China, China 2020 Series, Washington, DC, 1997. 